\title{
ВМІСТ АСКОРБІНОВОЇ КИСЛОТИ В ПЕЧІНЦІ Й НАДНИРКОВИХ ЗАЛОЗАХ ЩУРІВ ПРИ КОРИГУВАННІ АЛІМЕНТАРНОГО ГІПОТИРЕОЗУ ЙОДОМ РІЗНОЇ ХІМІЧНОЇ ПРИРОДИ
}

Вступ. Метаболізми вітамінів, мікроелементів і гормонів тісно пов'язані. Зв'язок між аскорбіновою кислотою і гормонами, зокрема похідними тирозину та стероїдами, зумовлює ії значення для діяльності щитоподібної залози, надниркових залоз і печінки. Найпоширенішою тиреоїдною патологією є гіпотиреоз, викликаний дефіцитом йоду. Для його лікування і профрілактики використовують сполуки, які містять йод різної хімічної природи.

Мета дослідження - провести порівняльне вивчення ефректу дії органічного і неорганічного йоду на вміст аскорбінової кислоти (АК) в тканинах печінки та надниркових залоз.

Методи дослідження. Дослідження проведено в модельних умовах аліментарного гіпотиреозу на 80 нелінійних білих щурах-самцях масою 0,140-0,160 ке, які впродовж 30 днів перебували на ізокалорійному крохмально-казеїновому раціоні. Коригування йододефріциту здійснювали трьома дозами йоду (21, 50, 100 мкг/маси тіла), які тварини одержували в харчовій суміші з калію йодидом (неорганічний йод) і йодбілковим препаратом із чорноморської промислової червоної водорості фрілофрори ребристої (органічний йод). Вміст АК у тканинах визначали із застосуванням реактиву Тільманса.

Результати й обговорення. За умов аліментарного гіпотиреозу рівень АК у тканинах печінки $i$ надниркових залоз був значно зниженим, що може вказувати на зменшення активності метаболічних процесів. Споживання обох йодовмісних речовин у дозі 21 мкг/ка супроводжувалося вірогідним збільшенням вмісту АК у печінці. Під впливом 50 мкг/кг йоду їі рівень у печінці й надниркових залозах сягав показників у інтактних щурів, однак при прийманні органічного йоду рівень АК був вищим. При споживанні 100 мкг/кг йоду вміст АК в органах вірогідно зменшувався відносно досягнутих показників і в надниркових залозах перебував на рівні параметрів у щурів, які не отримували йодовмісних сполук.

Висновки. Приймання як неорганічного, так і органічного йоду сприяє зростанню вмісту АК у печінці й надниркових залозах, що є передумовою активізування діяльності щитоподібної залози, при цьому вплив органічного йоду потужніший. Вплив обох йодовмісних препаратів на печінку більший, що може бути ознакою її більшої чутливості до посилення тиреоїдного гормонопоезу і вказувати на підвищення ії метаболічної активності.

КЛЮЧОВІ СЛОВА: гіпотиреоз; аскорбінова кислота; органічний йод; неорганічний йод; печінка; надниркові залози.

ВСТУП. Метаболізми вітамінів, мікроелементів і гормонів тісно пов'язані [1]. Особливий інтерес становить метаболізм аскорбінової кислоти (АК) - речовини, яка $є$ одним із регуляторів окисно-відновних реакцій і має виразну відновлювальну здатність [2-5]. Аскорбінова кислота $€$ кофрактором гідроксилаз, бере участь у катаболізмі тироксину, реакціях біосинтезу адреналіну й норадреналіну, тиреоїдних гормонів [2, 6]. В організмі АК у великій кількості міститься в печінці й надниркових залозах. 3 огляду на це, зв'язок між обміном АК і діяльністю щитоподібної (с) О. І. Рябуха, 2018. залози є безсумнівним, а визначення ії вмісту в тканинах внутрішніх органів при тиреоїдній патології становить науковий інтерес.

Найпоширенішою патологією щитоподібної залози є гіпотиреоз $[7,8]$. Зумовлений аліментарним дефіцитом йоду гіпотиреоз призводить до розладу обміну речовин, порушення діяльності серцево-судинної, нервової і статевої систем, зниження загальної резистентності організму, розладів імунної відповіді, зменшення антистресової стійкості $[9,10]$. Особливо несприятливого характеру перебіг гіпотиреозу набуває у дітей, в організмі яких відбуваються значні по- 
рушення фрізичного і психічного розвитку, що в подальшому може трансорормуватися в серйозну медико-соціальну проблему $[11,12]$.

Засобами профрілактики та подолання аліментарно зумовленого йододефріциту є застосування фрармакологічних препаратів калію йодиду [13], споживання харчових продуктів, йодованих йодидами чи йодатами [14, 15], або речовин, які містять органічний йод [16, 17]. Водночас $є$ дані, що сполуки йоду різної хімічної природи диференційовано впливають на синтетичну діяльність щитоподібної залози [18-20] й організм у цілому [21]. На думку деяких дослідників, для корекції екологічно зумовлених йододеоріцитів, обтяжених стресом, фрізичним перенапруженням, вагітністю, найбільш відповідною, а отже, й найеорективнішою є органічна форма йоду [22].

Мета дослідження - провести порівняльне вивчення ефректу дії органічного і неорганічного йоду на вміст АК у тканинах печінки та надниркових залоз.

МЕТОДИ ДОСЛІДЖЕННЯ. Дослідження проведено на 80 нелінійних білих щурах-самцях 3 початковою масою тіла 0,140-0,160 кг. Тварини впродовж 30 днів перебували на напівсинтетичному ізокалорійному крохмально-казеїновому раціоні. Водо- та жиророзчинні вітаміни надходили в кількості, рекомендованій для тварин даного виду і віку. Джерелом макро- і мікроелементів була сольова суміш J. H. Jones \& C. Foster, з якої для створення модельних умов аліментарно зумовленого гіпотиреозу вилучили сполуки йоду; фроновий вміст йоду в приготова- ному харчовому раціоні перебував у межах 1,6-1,8 мкг/щура/добу.

Коригування гіпотиреозу здійснювали сполуками неорганічного і органічного йоду, які тварини приймали з їжею. Джерелом неорганічного йоду в раціоні щурів був калію йодид, органічного - йодбілковий препарат, отриманий в Одеському фрізико-хімічному інституті ім. О. В. Богатського НАН України з чорноморської промислової червоної водорості фрілофори ребристої (Phyllophora nervosa); йод, який у препараті містився в кількості до 2 \%, перебував у фрормі зв'язаних із рослинними протеїнами йодамінокислот. Обидві йодовмісні речовини вводили в раціон у кількості, яка забезпечувала надходження в організм гістологічно підтверджених доз йоду: 21 мкг/кг маси тіла (мінімально діючої), 50 мкг/кг маси тіла (помірної), 100 мкг/кг маси тіла (значної).

Тварин поділили на 8 груп по 10 у кожній. Щури 1-ї групи, які додатково не отримували йодовмісних речовин, були контролем $\mathrm{K}_{1}$ для тварин інших груп. До раціону щурів 2-4 груп додавали, відповідно, 21, 50 та 100 мкг органічного йоду. Тварини 5-7 груп одержували аналогічні дози йоду неорганічної хімічної природи. Щурів 0 групи утримували на повноцінному загальновіваріальному кормі; вони слугували універсальним контролем К для тварин інших груп. На всіх етапах дослідження було дотримано вимог щодо гуманного ставлення до тварин (Страсбург, 1986). Умови дослідження наведено в таблиці 1.

Після закінчення терміну дослідження тварин було декапітовано під ефрірним наркозом;

Таблиця 1 - Умови проведення дослідження щодо визначення вмісту аскорбінової кислоти В тканинах печінки і надниркових залоз щурів $(\mathrm{n}=80)$

\begin{tabular}{|c|c|c|c|c|}
\hline Група тварин & $\begin{array}{c}\text { Умови } \\
\text { харчування }\end{array}$ & $\begin{array}{c}\text { Фонова кількість } \\
\text { йоду в раціоні, } \\
\text { мкг/щура/добу }\end{array}$ & $\begin{array}{c}\text { Кількість неорганічного } \\
\text { йоду калію йодиду } \\
\text { в раціоні, } \\
\text { мкг/кг маси тіла }\end{array}$ & $\begin{array}{c}\text { Кількість органічного } \\
\text { йоду йодбілкового } \\
\text { препарату в раціоні, } \\
\text { мкг/кг маси тіла }\end{array}$ \\
\hline $\begin{array}{l}0\left(K_{0}\right) \\
n=10\end{array}$ & \multicolumn{4}{|c|}{ Повноцінний загальновіваріальний корм } \\
\hline $\begin{array}{c}\text { 1-ша }\left(\mathrm{K}_{1}\right) \\
\mathrm{n}=10\end{array}$ & IKKP & $1,6-1,8$ & - & - \\
\hline $\begin{array}{c}\text { 2-га } \\
n=10\end{array}$ & IKKP & $1,6-1,8$ & 21 & - \\
\hline $\begin{array}{l}\text { 3-тя } \\
n=10\end{array}$ & IKKP & $1,6-1,8$ & 50 & - \\
\hline $\begin{array}{l}\text { 4-та } \\
n=10\end{array}$ & IKKP & $1,6-1,8$ & 100 & - \\
\hline $\begin{array}{l}5-т a \\
n=10\end{array}$ & IKKP & $1,6-1,8$ & - & 21 \\
\hline $\begin{array}{c}\text { 6-та } \\
n=10\end{array}$ & IKKP & $1,6-1,8$ & - & 50 \\
\hline $\begin{array}{l}\text { 7-ma } \\
n=10\end{array}$ & IKKP & $1,6-1,8$ & - & 100 \\
\hline
\end{tabular}

Примітка. ІККР - ізокалорійний крохмально-казеїновий раціон. 
їхні печінки та надниркові залози вилучено, відсепаровано від сполучної тканини і зважено, відповідно, на аналітичних та торсійних терезах. Вміст АК в органах визначали за реакцією Тільманса методом C. Farmer \& A. Abt. Цифрові результати дослідження представлено у вигляді середнього арифметичного показника і його стандартної похибки ( $\overline{\mathrm{X}} \pm \mathrm{m})$. Отримані цифрові параметри порівнювали між собою. Об'єктивність встановлення ефективності впливу обох препаратів та їх доз було забезпечено шляхом використання принципу методу фразового інтервалу, згідно з яким ідентифрікація фрактичного стану досліджуваної біологічної системи можлива через зіставлення ії̈ параметрів з показниками двох діаметрально протилежних контролів: отриманих за умов норми $\left(\mathrm{K}_{0}\right)$ та визначеної патології, яка підлягає коригуванню $\left(\mathrm{K}_{1}\right)$ [23]. Статистичну обробку отриманих параметрів здійснено із застосуванням математичної статистики; вірогідність даних оцінювали за t-критерієм Стьюдента при рівні статистичної значущості $\mathrm{p} \leq 0,05$.
РЕЗУЛЬТАТИЙ ОБГОВОРЕННЯ. ЯК ПОКаЗали результати досліджень (табл. 2), вміст АК у печінці та надниркових залозах інтактних тварин (0 група) становив, відповідно, $(0,70 \pm 0,04)$ i $(18,17 \pm 0,28)$ нмоль/л. Перебування в умовах йодного голодування (1-ша група) призводило до суттєвого зниження (відносно норми) вмісту АК у тканинах досліджуваних внутрішніх органів $(p<0,001)$.

Приймання 21 мкг органічного йоду (2-га група) сприяло зростанню рівня АК у внутрішніх органах, при цьому збільшення вмісту АК у печінці було вірогідним $((0,30 \pm 0,02)$ нмоль/л порівняно $3(0,15 \pm 0,02)$ нмоль/лу контролі $\left.\mathrm{K}_{1} ; \mathrm{p}<0,001\right)$.

Приймання органічного йоду в дозі 50 мкг (3-тя група) супроводжувалося різким зростанням вмісту АК і в печінці, і в надниркових залозах. Отримані результати були значно вищими за аналогічні показники у тварин як контрольної групи $\mathrm{K}_{1}$, так і попередньої 2-ї групи $(\mathrm{p}<0,001)$ та відповідали значенням досліджуваних параметрів у нормі (щодо даних інтактних щурів 0 групи $p>0,05)$.

Таблиця 2 - Вплив органічного і неорганічного йоду на вміст аскорбінової кислоти в печінці та надниркових залозах щурів у модельних умовах аліментарного дефріциту йоду $(\mathrm{n}=80)$

\begin{tabular}{|c|c|c|c|c|}
\hline \multirow[b]{2}{*}{$\begin{array}{l}\text { Група } \\
\text { тварин }\end{array}$} & \multirow[b]{2}{*}{$\begin{array}{c}\text { Хімічна природа } \\
\text { йоду, який додавали } \\
\text { до раціону }\end{array}$} & \multirow[b]{2}{*}{$\begin{array}{c}\text { Кількість йоду, } \\
\text { яку додавали } \\
\text { до раціону, мкг }\end{array}$} & \multicolumn{2}{|c|}{ Вміст аскорбінової кислоти } \\
\hline & & & $\begin{array}{c}\text { печінка, нмоль/л } \\
\overline{\mathrm{X}} \pm \mathrm{m}\end{array}$ & $\begin{array}{c}\text { надниркові залози, } \\
\text { нмоль/л } \\
\overline{\mathrm{X}} \pm \mathrm{m}\end{array}$ \\
\hline $\begin{array}{l}0\left(\mathrm{~K}_{0}\right) \\
\mathrm{n}=10\end{array}$ & \multicolumn{2}{|c|}{ Повноцінний загальновіваріальний корм } & $0,41 \pm 0,04$ & $18,17 \pm 0,28$ \\
\hline $\begin{array}{c}\text { 1-ша }\left(K_{1}\right) \\
n=10\end{array}$ & \multicolumn{2}{|c|}{ Не давали } & $\begin{array}{c}0,15 \pm 0,02 \\
p<0,001(0)\end{array}$ & $\begin{array}{c}9,66 \pm 0,36 \\
p<0,001(0)\end{array}$ \\
\hline $\begin{array}{c}\text { 2-га } \\
n=10\end{array}$ & Органічна & 21 & $\begin{array}{c}0,30 \pm 0,02 \\
p<0,001(0) \\
p<0,001(1)\end{array}$ & $\begin{array}{c}11,0 \pm 0,72 \\
p<0,001(0)\end{array}$ \\
\hline $\begin{array}{l}\text { 3-тя } \\
n=10\end{array}$ & Органічна & 50 & $\begin{array}{c}0,73 \pm 0,04 \\
p<0,001(1) \\
p<0,001(2)\end{array}$ & $\begin{array}{l}18,32 \pm 0,38 \\
p<0,001(1) \\
p<0,001(2)\end{array}$ \\
\hline $\begin{array}{c}\text { 4-та } \\
n=10\end{array}$ & Органічна & 100 & $\begin{array}{c}0,52 \pm 0,04 \\
p<0,001(0) \\
p<0,001(1) \\
p<0,001(2) \\
p<0,001\end{array}$ & $\begin{array}{l}10,94 \pm 0,88 \\
p<0,001(0) \\
p<0,001(3)\end{array}$ \\
\hline $\begin{array}{l}5-\mathrm{Ta} \\
\mathrm{n}=10\end{array}$ & Неорганічна & 21 & $\begin{array}{c}0,23 \pm 0,03 \\
p<0,001(0) \\
p<0,05(1)\end{array}$ & $\begin{array}{c}8,96 \pm 0,20 \\
p<0,001(0) \\
p<0,05(2)\end{array}$ \\
\hline $\begin{array}{c}\text { 6-та } \\
n=10\end{array}$ & Неорганічна & 50 & $\begin{array}{c}0,66 \pm 0,04 \\
p<0,001(1) \\
p<0,05(3) \\
p<0,001(5)\end{array}$ & $\begin{array}{l}17,87 \pm 0,47 \\
p<0,001(1) \\
p<0,001(5)\end{array}$ \\
\hline $\begin{array}{l}\text { 7-ма } \\
n=10\end{array}$ & Неорганічна & 100 & $\begin{array}{c}0,42 \pm 0,03 \\
p<0,001(0) \\
p<0,001(1) \\
p<0,001(5) \\
p<0,001(6)\end{array}$ & $\begin{array}{l}10,67 \pm 0,03 \\
p<0,001(0) \\
p<0,001(5) \\
p<0,001(6)\end{array}$ \\
\hline
\end{tabular}

Примітки:

1. $\bar{X}$ - середнє арифрметичне.

2. m - стандартна похибка середнього арифрметичного.

3. p - ступінь вірогідності; цифри в дужках вказують на номер групи, відносно якої вирахувано коесріцієнт р; показники $p>0,05$ у таблицю не вносили. 
При споживанні 100 мкг органічного йоду рівень АК у тканині печінки тварин 4-ї групи становив $(0,52 \pm 0,04)$ нмоль/л, що було більше за цисррові значення цього показника в щурів контрольної групи $\mathrm{K}_{1}$ і тварин 2-ї групи, до харчового раціону яких додавали 21 мкг органічного йоду $(p<0,001)$. Водночас отриманий показник був нижчим, ніж у тварин 3-ї групи (р<0,001). Вміст АК у надниркових залозах щурів обговорюваної групи був дещо вищим, ніжу тварин контрольної групи $\mathrm{K}_{1}$, проте різниця була невірогідною. Разом із тим він був вірогідно $(p<0,001)$ меншим, ніж у щурів 3-ї групи, і практично не відрізнявся від цисррового значення у тварин 2-ї групи.

Приймання 21 мкг неорганічного йоду (5-та група) сприяло суттєвому збільшенню (відносно контролюК $\left.{ }_{1}\right)$ рівня АКупечінці $((0,23 \pm 0,03)$ нмоль/л порівняно $3(0,15 \pm 0,02)$ нмоль/л; $p<0,05)$. Вміст АК у надниркових залозах щурів обговорюваної групи був вірогідно нижчим, ніж у тварин 2-ї групи, які отримували 21 мкг органічного йоду $(p<0,05)$, і перебував на рівні показника контролю $\mathrm{K}_{1}$.

Споживання 50 мкг неорганічного йоду (6-та група) супроводжувалося суттєвим збільшенням вмісту АК у печінці й надниркових залозах. Отримані результати були значно вищими за показники не тільки тварин контрольної групи $\mathrm{K}_{1}$, але й щурів попередньої 5-ї групи ( $p<0,001)$. Не встановлено статистично вірогідної різниці в циоррових значеннях вмісту АК у надниркових залозах тварин, які отримували по 50 мкг йоду в складі його органічних та неорганічних сполук (відповідно, 3-ї і 6-ї груп), та інтактних тварин 0 групи. Водночас рівень АК у печінці щурів обговорюваної групи був нижчим, ніж у 3-й групі $((0,66 \pm 0,04)$ нмоль/л відносно $(0,73 \pm 0,04)$ нмоль/л; $\mathrm{p}<0,05)$.

Вміст АК у печінці тварин 7-ї групи, харчовий раціон яких збагачували 100 мкг неорганічного йоду, був вірогідно більшим, ніж у щурів контрольної групи $\mathrm{K}_{1}$ і тварин 5-ї групи, які споживали 21 мкг неорганічного йоду $(p<0,001)$, проте меншим, ніж у щурів попередньої 6-ї групи, інтактних тварин 0 групи (p<0,001), щурів 4-ї групи, які приймали аналогічну дозу органічного йоду $((0,42 \pm 0,03)$ нмоль/л відносно $(0,52 \pm 0,04)$ нмоль/л; $p>0,05)$. Рівень АК у надниркових залозах тварин обговорюваної групи становив $(10,67 \pm 0,51)$ нмоль/л, що було дещо більше, ніж у щурів 5-ї групи $(p<0,001)$, але суттєво менше, ніж у тварин 6-ї групи, які споживали 50 мкг йоду йодиду $(p<0,001)$. Статистично вірогідних відмінностей у показниках вмісту АК у досліджуваних органах щурів обговорюваної групи і тварин 4-ї групи, які отримували аналогічну дозу органічного йоду, не встановлено.
Отже, перебування в умовах аліментарного десіциту йоду призводило до суттєвого $(p<0,001)$ зменшення рівня АК у тканинах печінки і надниркових залоз піддослідних щурів. 3 огляду на наявність фрункціонального зв'язку між гормонами щитоподібної та надниркових залоз [24] і важливу роль, яку печінка відіграє в метаболічних перетвореннях гормонів цих залоз [25], установлене вказує на те, що аліментарний гіпотиреоз призводить до значного зменшення активності метаболічних процесів у печінці на тлі зниження гормональної активності надниркових залоз.

Внесення до складу харчової суміші органічних і неорганічних сполук йоду сприяло збільшенню вмісту АК у тканинах печінки і надниркових залоз, що створювало передумови для підвищення гормональної активності щитоподібної залози. Водночас позитивний ефект залежав від хімічної природи і дози спожитого йоду. Так, зокрема, приймання 21 мкг як неорганічного, так і органічного йоду супроводжувалося збільшенням (відносно контролю $\mathrm{K}_{1}$ ) вмісту АК у печінці піддослідних щурів $(p<0,05$ та $p<0,001)$. Хоча при додатковому споживанні обох досліджуваних сполук не спостерігали вірогідної зміни цисррових показників вмісту АК у надниркових залозах (щодо контролю $\mathrm{K}_{1} \mathrm{p}>0,05$ ), ії рівень під впливом органічного йоду був вищим $(p<0,05)$, ніж при прийманні йоду неорганічної хімічної природи.

Споживання більшої дози йоду (50 мкг) сприяло зростанню рівня АК в органах. Так, у щурів, які отримували їі з неорганічним йодом, вміст АК у печінці й надниркових залозах сягав показників у інтактних тварин. Проте вищі показники рівня АК у печінці щурів, які споживали тотожну дозу органічного йоду, на мою думку, $є$ ознакою того, що йод органічної хімічної природи має потужніший вплив щодо активізування ії метаболічної діяльності.

При подальшому збільшенні дози йоду обох йодовмісних препаратів до 100 мкг рівень АК у досліджуваних органах, порівняно з досягнутими параметрами, вірогідно $(p<0,001)$ зменшився і в надниркових залозах відповідав значенням показника у щурів контрольної групи $\mathrm{K}_{1}$. Попри це вміст АК у печінці тварин обох груп перебував на рівні, не нижчому, ніж у інтактних щурів, що вказує на достатньо високий рівень обмінних процесів. Загалом при споживанні 50 та 100 мкг йоду обох йодовмісних сполук простежено певний паралелізм щодо їх впливу на вміст АК у досліджуваних органах.

ВИСНОВКИ. Отримані результати логічно розглядати як свідчення того, що за умов аліментарно зумовленого гіпотиреозу приймання 
як неорганічного, так і органічного йоду, викликаючи збільшення вмісту АК у печінці й надниркових залозах, створює передумови для активізування гормональної діяльності щитоподібної залози. Водночас необхідно зауважити, що дія органічного йоду потужніша. Вплив обох йодовмісних препаратів на печінку є більшим, ніж на

\section{СПИСОК ЛІТЕРАТУРИ}

1. Ребров В. Г. Витамины, макро- и микроэлементы / В. Г. Ребров, О. А. Громова. - М. : ГЭОТАР-Медиа, 2008. - 947 с.

2. Тимирханова Г. А. Витамин С: классические представления и новые фракты о механизмах биологического действия / Г. А. Тимирханова, Г.М.Абдуллина, И. Г. Кулагина // Вятский мед. вестн. - 2007. № 4. - C. 158-161.

3. Naidu K. A. Vitamin C in human health and disease is still a mystery? An overview [Internet] / K. A. Naidu // Nutrition Journal. - 2003. - No. 2. - P. 7. https://nutritionj. biomedcentral.com/articles/10.1186/1475-2891-2-7.

4. Blomhoff R. Dietary antioxidants and cardiovascular disease / R. Blomhoff // Current Opinion in Lipidology. 2005. - No. 16. - P. 47-54.

5. Walingo K. M. Role of vitamin C (ascorbic acid) on human health $-\mathrm{A}$ review [Internet] / K. M. Walingo // African Journal of Food, Agriculture, Nutrition and Development (AJFAND). - 2005. - Vol. 5, No 1. - https://tspace. library.utoronto.ca/bitstream/1807/7699/1/nd05011.pdf.

6. Figueroa-Méndez R. Vitamin $C$ in health and disease: its role in the metabolism of cells and redox state in the brain [Internet] / R. Figueroa-Méndez, S. RivasArancibia // Frontiers in Physiology. - 2015. - 6. P. 397. - doi: 10.3389/fphys.2015.00397.

7. Osama A. Hypothyroidism / A. Osama, R. G. Ahmed // A new look at hypothyroidism; D. Springer (Ed.). Rijeka, Croatia: InTech, 2017. - P. 1-20. - doi: 10.13140/2.1.1093.1201.

8. Stortoni P. Hypothyroidism, fertility and pregnancy / P. Stortoni, A. L. Tranquilli // Current topics in hypothyroidism with focus on development; E. Potluková (Ed.). Rijeka, Croatia : InTech, 2013. - P. 3-27. - http://dx.doi. org/10.5772/56084.

9. Городецкая И. В. Перифрерические механизмы стресс-протекторного эфрфекта йодсодержащих гормонов щитовидной железы / И. В. Городецкая, Е. А. Гусакова, О. В. Евдокимова // Вестн. ВГМУ. -2016. - 15, № 6. - C. 41-53.

10. Glinoer D. Pregnancy and iodine / D. Glinoer // Thyroid. - 2004. - Vol. 11, No 5. - P. 471-481.

11. Боднар П. М. Йододесріцитні розлади - актуальна медико-соціальна проблема / П. М. Боднар // Лікар. справа. Врач. дело. - 2001. - № 3. - С. 8-10.

12. Селективний скринінг уродженого гіпотиреозу у дітей із затримкою розумового розвитку / Г. Р. Акопян, надниркові залози, що може бути ознакою її більшої чутливості до посилення тиреоїдного гормонопоезу та підвищення загальної метаболічної активності.

Перспективи подальших досліджень полягають у вивченні особливостей йодонакопичувальної здатності щитоподібної залози за умов патології.

3. В. Осадчук, Н. І. Кіцера [та ін.] // Буковин. мед. вісн. - 2004. - 8, № 3-4. - С. 119-122.

13. Маменко М. Є. Йодний дефріцит та йододефріцитні захворювання / М. Є. Маменко // Перинатология и педиатрия. - 2013. - № 1 (53). - С. 97-105.

14. Йодный десицит: где мы теперь? (Эффрективность белорусской стратегии ликвидации йодного дефицита: 15-летний опыт) / Т. В. Мохорт, Н. Д. Коломиец, С. В. Петренко [и др.] // Междунар. эндокрин. журн. - 2015. - № 2. - С. 13-19.

15. Исследование профилактической эфрфективности биологически активной добавки биойод / Л. С. Большакова, Е. В. Литвинова, А. В. Кузина [и др.] // Фундаментальные исследования. - 2013. № 10, ч. 11. - С. 2401-2404.

16. Zimmermann M. B. Iodine Deficiency / M. B. Zimmermann // Endocrine Reviews. - 2009. - 30, No 4. P. 376-408.

17. Новые подходы в решении проблемы ликвидации йоддефицитных состояний / А. Ф. Цыб, В. А. Тутельян, Г. Г. Онищенко [и др.] // Довкілля та здоров'я. - 2004. - № 3. - С. 66-69.

18. Riabukha O. Application of new information technologies for the study of cell activity / O. Riabukha // Proceeding of the XIth International Conference on Perspective Technologies and Methods in MEMS Design (MEMSTECH'2015), [IEEE Cat. No. CFP1564A-PRT]. Lviv; Polyana (Ukraine), 2015. - P. 69-71. - http://www. worldcat.org/title/application-of-new-information-technologies-for-the-study-of-cell-activity/oclc/5912679282\& referer=brief_results\#reviews.

19. Рябуха О. І. Ультраструктурні особливості синтетичної діяльності фолікулярних тироцитів при прийманні органічного йоду в умовах аліментарного йододефіциту / О. І. Рябуха // Вісн. проблем біології і медицини. - 2017. - 2 (140), вип. 4. - С. 134-139.

20. Рябуха О. І. Дослідження синтетичної діяльності фролікулярних тироцитів при прийманні неорганічного йоду в умовах аліментарного йододесріциту / О. І. Рябуха // Вісн. проблем біології і медицини. 2017. - 3 (141), вип. 4. - С. 218-223. - doi: 10.29254/ 2077-4214-2017-4-3-141-218-223.

21. Рябуха О. І. Маса тіла як показник загального стану організму при прийманні йоду органічної і неорганічної хімічної природи в умовах оптимального забезпечення йодом / О.І.Рябуха // Вісн. проблем 
біології і медицини. - 2018. - 1 (142), вип. 1. - С. 97102. - doi: 10.29254/2077-4214-2018-1-1-142-97-102.

22. lodide insufficiency - consequences and prophylaxis / I. Turianica, L. Rostoka, L. Balint [et al.] // Zootehnie şi Biotehnologii. - 2009. - 42, No 1. - P. 300322.

23. Вероятностный метод диагностики в медицине. Основные виды врачебной логики / Е. В. Плащевая, В. А. Смирнов, Н. В. Нигей, В. А. Лысак // Пособие для практических занятий по медицинской инфрорматике. - Благовещенск : АГМА, 2014. - С. 176.

24. Tohei $A$. Studies on the functional relationship between thyroid, adrenal and gonadal hormones / A. Tohei // The Journal of Reproduction and Development. 2004. - Vol. 50, No 1. - P. 9-20.

25. Seike M. Endocrine disease and liver / M. Seike // The Liver in Systemic Diseases; H. Ohira (ed.). - Tokyo : Springer, 2016. - P. 251-270.

\section{REFERENCES}

1. Rebrov, V.G., \& Gromova, O.A. (2008). Vitaminy, makro- i mikroelementy [Vitamins, macro- and microelements]. Moscow: GEOTAR-Media [in Russian].

2. Timirkhanova, G.A., Abdullina, G.M., \& Kulagina, I.G. (2007). Vitamin C: klassicheskie predstavleniya i novye fakty o mekhanizmakh biologicheskogo deystviya [Vitamin C: classical conceptions and new facts about the mechanisms of biological action]. Vyatskiy meditsinskiy vestnik - Vyatsky Medical Bulletin, 4, 158-161 [in Russian]

3. Naidu, K.A. (2003). Vitamin C in human health and disease is still a mystery? An overview. Nutrition Journal, 2, 7. https://nutritionj.biomedcentral.com/ articles/10.1186/1475-2891-2-7.

4. Blomhoff, R. (2005). Dietary antioxidants and cardiovascular disease. Current Opinion in Lipidology, $16,47-54$.

5. Walingo, K.M. (2005). Role of vitamin C (ascorbic acid) on human health -A review. African Journal of Food, Agriculture, Nutrition and Development (AJFAND), 5 (1). https://tspace.library.utoronto.ca/bitstream/1807/7699/1/ nd05011.pdf.

6. Figueroa-Méndez, R., \& Rivas-Arancibia, S. (2015). Vitamin C in health and disease: its role in the metabolism of cells and redox state in the brain [Internet]. Frontiers in Physiology, 6, 397, doi: 10.3389/fphys. 2015.00397.

7. Osama, A., \& Ahmed, R.G. (2017). Hypothyroidism. In D. Springer (Ed.). A new look at hypothyroidism (pp. 1-20). Rijeka, Croatia: InTech.

8. Stortoni, P., \& Tranquilli, A.L. (2013). Hypothyroidism, fertility and pregnancy. In E. Potluková (Ed.). Current topics in hypothyroidism with focus on development (pp. 3-27). Rijeka, Croatia: InTech.

9. Gorodetskaya, I.V., Gusakova, E.A., \& Evdokimova, O.V. (2016). Perifericheskie mekhanizmy stressprotektornogo effekta yodsoderzhashchikh gormonov shchitovidnoy zhelezy [Peripheral mechanisms of the stress-protective effect of iodine-containing thyroid hormones]. Vestnik VGMU - Journal of Vitebsk State Medical University, 15 (6), 41-53 [in Russian].

10. Glinoer, D. (2004). Pregnancy and iodine. Thyroid, 11 (5), 471-481.

11. Bodnar, P.M. (2001). Yododefitsytni rozlady aktualna medyko-sotsialna problema [lodine deficiency disorders - urgent medical and social problem]. Likar. sprava - Doctor's case, 3, 8-10 [in Ukrainian].

12. Akopian, H.R., Osadchuk, Z.V., Kitsera, N.I., Chaikovska, H.S., Kovaliv, I.B., Kostsyk, N.R., ...
Viitovych, I.V. (2004). Selektyvnyi skryninh urodzhenoho hipotyreozu u ditei iz zatrymkoiu rozumovoho rozvytku [Selective screening of congenital thyroid deficiency in children with mental retardation]. Bukovynskyi medychnyi visnyk - Bukovyna Medical Journal, 8 (3-4), 119-122 [in Ukrainian].

13. Mamenko, M.Ye. (2013). Yodnyi defitsyt ta yododefitsytni zakhvoriuvannia [lodine deficiency and iodine deficiency disorders]. Perinatolohiia i pediatriia Perinatology and Pediatrics, 1(53), 97-105 [in Ukrainian].

14. Mokhort, T.V., Kolomiets, N.D., Petrenko, S.V., Fedorenko, Ye.V., \& Mokhort, Ye.G. (2015). Yodnyy defitsit: gde my teper? (Effektivnost belorusskoy strategii likvidatsii yodnogo defitsita: 15-letniy opyt) [Iodine deficiency: where are we now? (Efficiency of Belarusian strategy in elimination of iodine deficiency: 15-year experience)]. Mezhdunarodnyy endokrinologicheskiy zhurnal - International Endocrinology Journal, 2 (66), 13-19 [in Russian].

15. Bolshakova, L.S., Litvinova, E.V., Kuzina, A.V., Lisiyn, A.B., \& Chernuha, I.M. (2013). Issledovanie profilakticheskoy effektivnosti biologicheski aktivnoy dobavki bioyod [Study of prophylactic effectiveness of the biological active additives bioiodine]. Fundamentalnyye issledovaniya - Fundamental Researches, 10/11, 2401-2404 [in Russian].

16. Zimmermann, M.B. (2009). Iodine deficiency. Endocrine Reviews, 30(4), 376-408.

17. Tsyb, A.F., Tutelyan, V.A., Onishchenko, G.G., Shakhtarin, V.V., Parshyn, V.S., Roziyev, R.A., ... Proshyn, A.D. (2004). Novyye podkhody v reshenii problemy likvidatsii yoddefitsitnykh sostoyaniy [New approaches for solution of the problem of iodine deficiency state liquidation]. Dovkillia ta zdorovia - Environment \& Health, 3, 66-69 [in Russian].

18. Riabukha, O. (2015). Application of new information technologies for the study of cell activity. In Proceedings of the XIth International Conference - MEMSTECH'2015 (IEEE Cat. No. CFP1564A-PRT), 69-71. Sept. 2-6, Lviv-Poliana, Ukraine. Retrieved from: http:// www.worldcat.org/title/application-of-new-informationtechnologies-for-the-study-of-cell-activity/oclc/ 5912679282\&referer=brief_results\#reviews.

19. Riabukha, O.I. (2017). Ultrastrukturni osoblyvosti syntetychnoi diialnosi folikuliarnykh tyrotsytiv pry pryimanni orhanichnoho yodu $v$ umovakh alimentarnoho yododefitsytu [Ultrastructural features of the follicular thyrocytes synthetic activity while taking organic iodine under conditions of alimentary iodine deficiency]. Visnyk 
problem biolohii i medytsyny - Bulletin of Problems in Biology and Medicine, 4, 2(140), 134-139 [in Ukrainian].

20. Riabukha, O.I. (2017). Doslidzenia syntetychnoi diialnosti folikuliarnykh tyrotsytiv pry pryimanni neorhanichnoho yodu v umovakh alimentarnoho yododefitsytu [Study of the follicular thyrocytes synthetic activity while taking inorganic iodine under conditions of alimentary iodine deficiency]. Visnyk problem biolohii i medytsyny - Bulletin of Problems in Biology and Medicine, 4, 3 (141), 218-223, doi: 10.29254/2077-4214-2017-4-3141-218-223 [in Ukrainian].

21. Riabukha, O.I. (2018). Masa tila yak pokaznyk zahalnoho stanu orhanizmu pry pryimanni yodu orhanichnoi i neorhanichnoi khimichnoi pryrody v umovakh optymalnoho zabezpechennia yodom [Body weight as an indicator of the organism's general condition while receiving iodine of organic and inorganic chemical origin under conditions of the optimal iodine supplementing]. Visnyk problem biolohii i medytsyny - Bulletin of Problems in
Biology and Medicine, 1, 1(142), 97-102, doi: 10.29254/ 2077-4214-2018-1-1-142-97-102 [in Ukrainian].

22. Turianica, I., Rostoka, L., Balint, L., Hluchy, S., \& Kulcicky, O. (2009). lodide insufficiency-consequences and prophylaxis. Zootehnie şi Biotehnologii, 42 (1), 300322.

23. Plashchevaya, E.V., Smirnov, V.A., Nigej, N.V., \& Lysak, V.A. (2014). Veroyatnostnyy metod diagnostiki $\checkmark$ meditsine. Osnovnye vidy vrachebnoy logiki [Probabilistic method of diagnosis in medicine. The main types of medical logic]. In Posobie dlya prakticheskih zanyatiy po medicinskoy informatike [Manual for practical training in medical informatics] (p.176). Blagoveshchensk: AGMA [in Russian].

24. Tohei, A. (2004). Studies on the functional relationship between thyroid, adrenal and gonadal hormones. Journal of Reproduction and Development, 50 (1), 9-20.

25. Seike, M. (2016). Endocrine Disease and Liver. In H. Ohira (Ed.). The Liver in Systemic Diseases (pp. 251-270). Tokyo: Springer.

Зв'язок роботи з науковими програмами, планами, темами. Робота є складовою частиною науково-дослідної теми "Патогенетичні аспекти фрормування алергічних і запальних процесів, впливів на реактивність організму та фрармакотерапія" № державної реєстрації 0111U000126.

\section{СОДЕРЖАНИЕ АСКОРБИНОВОЙ КИСЛОТЫ В ПЕЧЕНИ И НАДПОЧЕЧНИКАХ КРЫС ПРИ КОРРЕКЦИИ АЛИМЕНТАРНОГО ГИПОТИРЕОЗА ЙОДОМ РАЗНОЙ ХИМИЧЕСКОЙ ПРИРОДЫ}

\section{Резюме}

Вступление. Метаболизмы витаминов, микроэлементов и гормонов взаимосвязаны. Связь между аскорбиновой кислотой и гормонами, в частности производными тирозина и стероидами, обусловливает ее значение для деятельности щитовидной железы, надпочечников и печени. Самой распространенной тиреоидной патологией является гипотиреоз, вызванный дефицитом йода. Для его лечения и профрилактики используют соединения, содержащие йод разной химической природы.

Цель исследования - провести сравнительное изучение эфрфекта воздействия органического и неорганического йода на содержание аскорбиновой кислоты (АК) в тканях печени и надпочечников.

Методы исследования. Исследование проведено в модельных условиях алиментарного гипотиреоза на 80 нелинейных белых крысах-самцах массой 0,140-0,160 к2, которые на протяжении 30 дней пребывали на изокалорийном крахмально-казеиновом рационе. Коррекцию йододефицита осуществляли тремя дозами йода (21, 50, 100 мкг/массы тела), которые животные получали в пищевой смеси с калия йодидом (неорганический йод) и йодбелковым препаратом из черноморской промышленной красной водоросли фриллофоры ребристой (органический йод). Содержание АК в тканях определяли с использованием реактива Тильманса.

Результаты и обсуждение. В условиях алиментарного гипотиреоза уровень АК в тканях печени и надпочечников был значительно сниженным, что может указывать на уменьшение активности метаболических процессов. Потребление обоих йодсодержащих веществ в дозе 21 мкг/ка сопровождалось достоверным увеличением содержания АК в печени. Под влиянием 50 мкг/кг йода ее уровень в печени и надпочечниках достигал показателей у интактных крыс, однако при приеме органического йода уровень АК был выше. При потреблении 100 мкг/кг йода содержание АК в органах достоверно уменьшалось относительно достигнутых показателей и в надпочечниках было на уровне параметров у крыс, которые не получали йодсодержащих веществ. 
Выводы. Прием как неорганического, так и органического йода способствует возрастанию содержания АК в печени и надпочечниках, что является предпосылкой активизации деятельности щитовидной железы, при этом воздействие органического йода более мощное. Влияние обоих йодсодержащих препаратов на печень выражено больше, что может быть признаком ее большей чувствительности к усилению тиреоидного гормонопоэза и указывать на повышение ее метаболической активности.

КЛЮЧЕВЫЕ СЛОВА: гипотиреоз; аскорбиновая кислота; органический йод; неорганический йод; печень; надпочечники.

\author{
O. I. Ryabukha
}

LVIV MEDICAL INSTITUTE

\title{
THE CONTENT OF ASCORBIC ACID IN THE LIVER AND ADRENAL GLANDS OF RATS DURING CORRECTION OF ALIMENTARY HYPOTHYROSIS BY AN IODINE OF A DIFFERENT CHEMICAL NATURE
}

\section{Summary}

Introduction. Metabolisms of vitamins, trace elements and hormones are closely linked. The connection between ascorbic acid and hormones, in particular derivatives of tyrosine and steroids, determines its importance for the activity of the thyroid gland, adrenal glands and liver. The most common thyroid pathology is hypothyroidism, caused by iodine deficiency. For its treatment and prevention, compounds that contain iodine of different chemical nature are used.

The aim of the study - to compare the effect of the action of organic and inorganic iodine on the content of ascorbic acid $(A A)$ in the liver and adrenal glands.

Research Methods. The study was conducted in the model conditions of alimentary hypothyroidism on 80 white nonlinear male rats weighing $0.140-0.160 \mathrm{~kg}$, which for 30 days were in an isocaloric starch-casein ration. Adjustment of iodine deficiency was carried out on three doses of iodine (21, 50, $100 \mu \mathrm{g} / \mathrm{kg}$ body weight), which animals uptaked with potassium iodide (inorganic iodine) and iodine-protein preparation from the Black Sea industrial red algae of Phyllophora nervosa (DC.) Grev (organic iodine). The content of AA in the tissues was determined using Tillman's reagent.

Results and Discussion. In conditions of alimentary hypothyroidism, the level of AA in the investigated organs was significantly reduced, which may indicate a decrease in the activity of metabolic processes. The consumption of both iodine-containing substances at a dose of $21 \mu \mathrm{g} / \mathrm{kg}$ was accompanied by a probable increase in the content of $A A$ in the liver. Under the influence of $50 \mu \mathrm{g} / \mathrm{kg}$ iodine, its level in the rat's liver and adrenal glands reached the levels of intact rats, but under use of organic iodine the level of AA was higher. When receiving $100 \mu \mathrm{g} / \mathrm{kg}$ of iodine, the content of AA in organs was significantly reduced relative to the achieved parameters and in the adrenal glands was at the level of parameters of rats that did not consume iodine-containing compounds.

Conclusions. The intake of both inorganic and organic iodine contribute to an increase in the content of $A A$ in the liver and adrenal glands, which is a prerequisite for activating the activity of the thyroid gland, while the effect of organic iodine is more powerful. The effect of both iodine-containing preparations on the liver is greater, which may be a sign of its greater sensitivity to the strengthening of thyroid hormonepoise and indicate an increase in its metabolic activity.

KEY WORDS: hypothyrosis; ascorbic acid; organic iodine; inorganic iodine; liver; adrenal glands.

Отримано 23.01.18

Адреса для листування: О. І. Рябуха, Львівський медичний інститут, вул. Поліщука, 76, Львів, 79015, Україна, е-таil: oriabuha@ukr.net. 